\title{
EVALUASI KEBIJAKAN PEMERINTAH DALAM MENJAGA STABILITAS PERTUMBUHAN EKONOMI TAHUN 2013
}

\author{
Ahmad Azmy \\ Universitas Tanri Abeng
}

\begin{abstract}
This study aimed to evaluate government policies through several fiscal and monetary stimulus in stabilizing economic growth through interest rate policy, the money supply and inflation in Indonesia during 2013. The variables used were the $B$ I rate, the money supply (M2), and inflation. This study using Pearson correlation analysis to measure the relationship between these three variables. The results of this study indicate that the $B I$ rate has a significant positive correlation to the amount of money supply (M2). BI rate has no significant negatif correlation to inflation. While the money supply has no significant positive correlation to inflation (M2). These anomalies can be caused by fluctuation of currency exchange rates on foreign currency Indonesia, balance of payments, current account deficit, or the amount of government debt that is maturing. For the case of Indonesia, the policy to control inflation through interest rate increases become ineffective if some basic assumptions both Keynesian and Monetarist not met.
\end{abstract}

Keywords: Money Supply (M2), Inflation, Monetarist Model, Economic Growth.

\begin{abstract}
Abstrak
Penelitian ini bertujuan untuk mengevaluasi kebijakan pemerintah melalui beberapa stimulus fiskal dan moneter dalam menjaga stabilitas pertumbuhan ekonomi melalui kebijakan suku bunga, jumlah uang beredar dan inflasi di Indonesia selama tahun 2013. Variabel yang digunakan adalah BI Rate, jumlah uang beredar (M2), dan inflasi. Penelitian ini menggunakan analisis korelasi pearson untuk mengukur hubungan antara ketiga variabel tersebut. Hasil dari penelitian ini menunjukkan bahwa BI Rate memiliki korelasi positif signifikan terhadap jumlah uang beredar (M2). BI Rate memiliki korelasi negatif tidak signifikan terhadap inflasi. Sedangkan uang beredar memiliki hubungan positif tidak signifikan terhadap inflasi (M2). Anomali ini bisa disebabkan oleh gejolak nilai kurs mata uang Indonesia terhadap mata uang asing, neraca pembayaran, defisit neraca berjalan ataupun besarnya hutang pemerintah yang jatuh tempo. Untuk kasus Indonesia, kebijakan pengendalian inflasi melalui peningkatan suku bunga menjadi tidak efektif jika beberapa asumsi dasar baik model Keynes maupun Monetarist tidak terpenuhi.
\end{abstract}

Kata Kunci: Uang Beredar (M2), Inflasi, Model Moneter, Pertumbuhan Ekonomi

Diterima: 15 Pebruari 2014; Direvisi: 15 April 2014; Disetujui: 22 April 2014 


\section{PENDAHULUAN}

Selama tahun 2013 pemerintah mengeluarkan beberapa kebijakan strategis untuk menjaga pertumbuhan ekonomi di Indonesia. Beberapa indikator ekonomi yang dapat menunjukkan kesuksesan sebuah kebijakan pemerintah dapat dilihat dengan beberapa variabel seperti inflasi, BI Rate, jumlah uang beredar (M2), nilai eksporimport, Gross Domestic Product (GDP), dan lain sebagainya. Inflasi digunakan untuk menganalisis stabilitas harga dalam perekonomian sebuah negara. BI Rate adalah suku bunga kebijakan yang mencerminkan sikap kebijakan moneter yang ditetapkan oleh bank Indonesia dan diumumkan kepada publik. Jumlah uang beredar (M2) digunakan untuk menganalisis daya beli masyarakat dalam melakukan transaksi ekonomi dengan pihak lain sehingga menciptakan kelancaran arus barang dan jasa. Masalah dalam penelitian ini adalah untuk menganalisis kebijakan pemerintah dalam menjaga pertumbuhan ekonomi dengan menggunakan tiga variabel yaitu BI Rate, Inflasi, dan jumlah uang beredar (M2). Ketiga variabel ini digunakan untuk melihat bagaimana setiap stimulus pemerintah dalam menjaga pertumbuhan ekonomi sehingga menciptakan stabilitas perekonomian di Indonesia.

Pembangunan ekonomi merupakan tahapan proses yang mutlak dilakukan oleh suatu bangsa untuk dapat meningkatkan taraf hidup dan kesejahteraan seluruh bangsa tersebut. Pembangunan ekonomi suatu Negara tidak dapat dilakukan dengan berbekal tekad yang membaja dari seluruh rakyatnya untuk membangun, tetapi lebih dari itu harus didukung pula oleh ketersediaan sumber daya baik sumber daya alam, sumber daya manusia, dan sumber daya modal produktif. Dengan kata lain, tanpa adanya daya dukung yang cukup kuat dari sumber daya produktif, maka pembangunan ekonomi mustahil dapat dilaksanakan dengan baik dan memuaskan (Hamzah, 2006).

Inflasi merupakan dilema yang menghantui perekonomian setiap negara. Perkembangannya yang terus meningkat memberikan hambatan pada pertumbuhan ekonomi ke arah yang lebih baik. Banyak kajian membahas inflasi, tidak hanya cakupan regional, nasional, namun juga internasional. Inflasi cenderung terjadi pada negara-negara berkembang seperti halnya Indonesia dengan struktur perekonomian bercorak agraris. Kegagalan atau guncangan dalam negeri akan menimbulkan fluktuasi harga di pasar domestik dan berakhir dengan inflasi pada perekonomian (Baasir, 2003). 
Inflasi merupakan fenomena ekonomi yang selalu menarik untuk dibahas terutama berkaitan dengan dampaknya yang luas terhadap agregat makro ekonomi. Pertama, inflasi domestik yang tinggi menyebabkan tingkat balas jasa riil terhadap aset finansial domestik menjadi rendah (bahkan seringkali negatif), sehingga dapat mengganggu mobilisasi dana domestik dan bahkan dapat mengurangi tabungan domestik yang menjadi sumber dana investasi. Kedua, inflasi dapat menyebabkan daya saing barang ekspor berkurang dan dapat menimbulkan defisit dalam transaksi berjalan dan sekaligus dapat meningkatkan utang luar negeri. Ketiga, inflasi dapat memperburuk distribusi pendapatan dengan terjadinya transfer sumber daya dari konsumen dan golongan berpenghasilan tetap kepada produsen. Keempat, inflasi yang tinggi dapat mendorong terjadinya pelarian modal ke luar negeri. Kelima, inflasi yang tinggi akan menyebabkan kenaikan tingkat bunga nominal yang dapat mengganggu tingkat investasi yang dibutuhkan untuk memacu tingkat pertumbuhan ekonomi tertentu (Hera Susanti dkk, 1995).

Menurut Boediono (1992), pada dasarnya terdapat 3 (tiga) teori tentang inflasi, yaitu: Teori Kuantitas, yaitu teori yang menganalisis peranan dari jumlah uang beredar dan ekspektasi masyarakat mengenai kemungkinan kenaikan harga (peranan psikologis). Menurut teori ini, pertambaham volume uang yang beredar sangat dominan terhadap kemungkinan timbulnya inflasi. Kenaikan harga yang tidak dibarengi dengan pertambahan jumlah uang beredar sifatnya hanya sementara. Dengan demikian menurut teori ini, apabila jumlah uang tidak ditambah, kenaikan harga akan berhenti dengan sendirinya. Untuk ekspektasi berdasarkan teori ini, walaupun jumlah uang bertambah tetapi masyarakat belum menduga adanya kenaikan, maka pertambahan uang beredar hanya akan menambah simpanan atau uang kas karena belum dibelanjakan. Dengan demikian harga barang-barang tidak naik. Jika masyarakat menduga bahwa besok bahwa dalam waktu dekat harga barang akan naik, masyarakat cenderung membelanjakan uangnya karena khawatir akan penurunan nilai uang, sehingga akan memicu inflasi.

Teori Inflasi Keyness, menurut Keynes inflasi pada dasarnya disebabkan oleh ketidakseimbangan antara permintaan masyarakat (demand) terhadap barangbarang dagangan (stock), dimana permintaan lebih banyak dibandingkan dengan barang yang tersedia, sehingga terdapat gap yang disebut inflationaty gap. 
Teori Struktural, teori ini berlandaskan kepada struktur perekonomian dari suatu negara (umumnya negara berkembang). Menurut teori ini, inflasi disebabkan oleh ketidakelastisan penerimaan ekspor. Hasil ekspor meningkat namun lambat dibandingkan dengan pertumbuhan sektor lainnya. Peningkatan hasil ekspor yang lambat antara lain disebabkan karena harga barang yang diekspor kurang menguntungkan dibandingkan dengan kebutuhan barang-barang import yang harus dibayar. Dengan kata lain daya tukar barang-barang negara tersebut semakin memburuk. Ketidakelastisan penawaran produksi bahan makanan. Terjadi ketidakseimbangan antara pertumbuhan produksi bahan makanan dengan jumlah penduduk, sehingga mengakibatkan kelonjakan kenaikan harga bahan makanan. Hal ini dapat menimbulkan tuntutan kenaikan upah dari kalangan buruh / pegawai tetap akibat kenaikan biaya hidup. Kenaikan upah selanjutnya akan meningkatkan biaya produksi dan mendorong terjadinya inflasi.

Menurut Bank Indonesia (2012) BI Rate adalah suku bunga kebijakan yang mencerminkan sikap kebijakan moneter yang ditetapkan oleh Bank Indonesia dan diumumkan kepada masyarakat. BI Rate inilah yang kemudian akan diatur besarannya untuk menjaga inflasi agar tetap stabil dan rendah. Mekanisme bekerjanya $\mathrm{BI}$ Rate hingga mempengaruhi tujuan akhir kebijakan moneter yang berupa inflasi disebut sebagai mekanisme kebijakan moneter (Bank Indonesia, 2012).

Perubahan BI Rate akan mempengaruhi beberapa variabel makroekonomi yang kemudian diteruskan kepada inflasi. Perubahan berupa peningkatan level BI Rate bertujuan untuk mengurangi laju aktifitas ekonomi yang mampu memicu inflasi. Pada saat level BI Rate naik maka suku bunga kredit dan deposito pun akan mengalami kenaikan. Ketika suku bunga deposito naik, masyarakat akan cenderung menyimpan uangnya di bank dan jumlah uang yang beredar berkurang. Pada suku bunga kredit, kenaikan suku bunga akan merangsang para pelaku usaha untuk mengurangi investasinya karena biaya modal semakin tinggi. Hal demikianlah yang meredam aktivitas ekonomi dan pada akhirnya mengurangi tekanan inflasi (Bank Indonesia, 2012).

Sebaliknya pada saat level BI Rate turun maka suku bunga kredit dan deposito pun akan mengalami penurunan. Ketika suku bunga deposito turun, keinginan masyarakat untuk menyimpan uangnya di bank akan menurun. Kondisi ini memicu peningkatan jumlah uang beredar yang selanjutnya akan meningkatkan transaksi 
masyarakat. Pada suku bunga kredit, penurunan suku bunga akan merangsang peningkatan permintaan kredit dari pelaku usaha karena murahnya biaya modal. Pada kondisi ini maka keadaan ekonomi yang lesu akan segera meningkat. Adanya tambahan likuiditas yang ada di masyarakat untuk bertransaksi akan diimbangi oleh peningkatan produksi di sisi pelaku usaha maka pada akhirnya akan meningkatkan kegiatan ekonomi (Bank Indonesia, 2012).

Menurut Solikin dan Suseno (2002), uang yang beredar merupakan kewajiban system moneter terhadap sektor swasta domestik atau masyarakat, yang terdiri dari uang kartal (currency), uang giral (demand deposit), dan uang kuasi (quasi money). Sistem moneter adalah otoritas moneter (bank sentral) dan bank umum, dimana Bank Indonesia sebagai bank sentral merupakan lembaga yang mengeluarkan dan mengedarkan uang kartal, sedangkan bank umum mengeluarkan dan mengedarkan uang giral serta uang kuasi.

Uang adalah konsep sentral dalam The General Theory Keynes. Menurut Keynesian, penambahan jumlah uang beredar akan menurunkan tingkat bunga. Keynes tidak memandang bahwa jumlah uang merupakan faktor eksogen seperti halnya Monetarist. Monetarist menganggap bahwa perubahan jumlah uang beredar tidak terpengaruh kegiatan ekonomi. Dengan kata lain jumlah uang beredar merupakan faktor eksogen. Keynesian sebaliknya, menganggap bahwa jumlah uang beredar sangat dipengaruhi oleh kegiatan ekonomi (Nopirin, 2000). Dalam teori moneter, Keynesian lebih menekankan pada mekanisme tidak langsung, yakni kebijakan moneter pertama-tama mempengaruhi sistem moneter dengan merubah tingkat bunga. Oleh karena itu, indikator kebijakan moneter yang penting satu di antaranya tingkat bunga. Menurut Monetarist, kenaikan jumlah uang beredar dalam jangka panjang akan menaikkan tingkat bunga (Nopirin, 2000).

Efektifitas kebijakan moneter dapat diketahui dengan mengetahui pada sejauh mana kebijakan moneter dapat mengubah kondisi pasar uang (yang diukur dengan pertumbuhan jumlah uang beredar dan perubahan tingkat bunga) (Sudirman, 2011).

Para ekonom klasik cenderung untuk mengartikan uang beredar sebagai currency karena uang ini yang benar-benar merupakan daya beli yang langsung bisa digunakan (dibelanjakan) dan oleh karena itu langsung mempengaruhi harga-harga barang (Boediono, 1996). 
Dalam The Quantity Theory of Money aliran klasik, Irving Fisher dengan The Transaction Equation of Exchange-nya secara umum mengekspresikan persamaan kuantitas uang sebagai sebagai berikut: $M V=P T$ (Kurihara, 1970: 14). $P=M V / T$, sehingga $P$ di sini dinotasikan sebagai tingkat harga umum. $M$ adalah kuantitas dari uang, $\mathrm{V}$ adalah kecepatan peredaran dari uang, sedangkan $\mathrm{T}$ adalah volume dari perdagangan.

MV sebenarnya adalah pengeluaran agregat, yang merupakan volume dari perdagangan dikali harga rata-rata (PT) atau penerimaan agregat. Persamaan tersebut ditranfer dalam bentuk $P=M V / T$ diartikan sebagai variasi tingkat harga umum secara langsung merupakan kuantitas dari uang dikali dengan kecepatan peredarannya, dibagi dengan volume barang yang diperdagangkan.

M dalam persamaan transaksi dinyatakan sebagai jumlah total dari uang yang terdiri dari currency dan demand deposits, termasuk didalamnya uang berupa valutavaluta asing yang ada di bank, time deposits, dan cadangan dalam bentuk surat-surat berharga lainnya. Lebih tegas lagi bahwa $\mathrm{M}$ adalah jumlah uang beredar dalam perekonomian.

Jumlah uang beredar biasanya ditentukan oleh (a) uang inti, yang terdiri dari cadangan emas, uang yang dimiliki pemerintah, dan kredit bank sentral, (b) proporsi antara demand deposits dan uang kas yang dipegang oleh masyarakat umum, dan (c) rasio antara cadangan dan demand deposits.

Dalam teori tingkat bunga, bunga mempunyai fungsi alokatif dalam perekonomian, khususnya dalam penggunaan uang. "Masalah alokasi penggunaan faktor produksi untuk menghasilkan barang yang digunakan dikemudian hari, fungsi inilah yang antara lain dilakukan oleh tingkat bunga, yakni alokasi faktor produksi untuk menghasilkan barang dan jasa yang dipakai sekarang dan dikemudian hari” (Nopirin, 2000).

Dalam kepustakaan teori moneter, dikenal tingkat bunga nominal dan tingkat bunga riil. Tingkat bunga nominal sering dilawankan dengan tingkat bunga riil. Tingkat bunga riil adalah tingkat bunga nominal minus laju inflasi yang terjadi selama periode yang sama. Bagi debitur, tingkat bunga riil merupakan imbalan riil bagi pengorbannya untuk menyerahkan penggunaan uangnya untuk jangka waktu tertentu. 
Mengenai tingkat bunga riil, ada satu teori yang menjelaskannya. Teori tersebut adalah dari Irving Fisher yang juga pencetus equation of exchange terkait dengan konsep time preference. Menurut Fisher, dalam jangka panjang tingkat bunga riil tidak dipengaruhi oleh laju inflasi (Boediono, 1980). Berdasarkan struktur tingkat bunga atau disebut terms structure of interest rates, tingkat bunga dapat dibagi menjadi dua: (1) tingkat bunga jangka pendek, (2) tingkat bunga jangka panjang.

\section{Kebijakan Ekonomi Pemerintah Tahun 2013}

Pada Triwulan pertama, Bank Indonesia memutuskan untuk mempertahankan BI Rate pada level $5.75 \%$. Tujuan pengambilan keputusan tersebut adalah untuk memperkuat operasi moneter melalui penyerapan akses likuiditas yang lebih besar ke tenor jangka panjang. Bank Indonesia memperkuat koordinasi bersama Pemerintah untuk menekan defisit transaksi berjalan dan meminimalkan potensi tekanan inflasi dari sisi volatile makanan termasuk kebijakan impor hortikultura. Cadangan devisa pada akhir Maret 2013 mencapai 104,8 miliar dolar AS atau setara dengan 5,7 bulan impor dan pembayaran utang luar negeri Pemerintah, di atas standar kecukupan internasional. Nilai tukar rupiah pada triwulan pertama mencapai Rp.9680 dan diprediksi pada triwulan kedua juga akan mengalami kenaikan moderat.

Gejolak harga pangan mendorong tingginya inflasi pada Maret 2013. Inflasi IHK Maret 2013 mencapai $0.63 \%$ ( $\mathrm{mtm}$ ) atau 5.90\% (yoy) di atas rata-rata historisnya. Inflasi kelompok volatile makanan tercatat sangat tinggi yaitu $2,44 \%(\mathrm{mtm})$ atau $14.20 \%$ (yoy), khususnya pada komoditas bawang putih, bawang merah, dan cabai akibat gangguan pasokan terkait dengan kebijakan impor yang diterapkan oleh pemerintah. Di sisi lain inflasi masih stabil sebesar $4.21 \%$ (yoy) sejalan dengan ekspektasi inflasi masyarakat yang masih terjaga dan kapasitas produksi yang masih memadai dalam menjaga daya beli masyarakat. Kondisi stabilitas keuangan Indonesia masih terjaga yang ditunjukkan denga rasio CAR (Capital Adequacy Ratio) yang berada jauh di atas minimum $8 \%$ dan terjaganya rasio kredit bermasalah (NPL/Non Performing Loan) gross di bawah 5\%. Sementara itu, pertumbuhan kredit hingga akhir Februari 2013 mencapai 23,4\% (yoy), meningkat dibandingkan dengan bulan sebelumnya. Kredit modal kerja dan kredit investasi masih tumbuh cukup tinggi sebesar 24,5\% (yoy) dan 25,4\% (yoy). 
Pada triwulan kedua Bank Indonesia memutuskan untuk menaikkan BI Rate sebesar $6,5 \%$ dengan suku bunga Deposit Facility naik 50 bps menjadi 4,75\% dan suku bunga Lending Facility tetap pada level 6,75\%. Kebijakan tersebut ditempuh untuk memastikan inflasi yang meningkat pasca kenaikan harga bahan bakar diharapkan dapat segera normal dan tidak menganggu tingkat inflasi. Ada beberapa kebijakan Bank Indonesia dalam menjaga pertumbuhan ekonomi Indonesia pada Triwulan kedua dengan melanjutkan stabilisasi nilai tukar rupiah yang sesuai kondisi fundamentalnya dan menjaga kecukupan likuiditas di pasar valas. Menyempurnakan ketentuan loan to value ratio sektor properti terkait Kredit Pemilikan Rumah (KPR)/Kredit Pemilikan Apartemen (KPA) untuk tipe-tipe tertentu. Memperkuat langkah koordinasi dengan Pemerintah dengan fokus meminimalkan tekanan inflasi serta memelihara stabilitas makroekonomi dan sistem keuangan

Pertumbuhan ekonomi Indonesia pada tahun 2013 diperkirakan pada kisaran 5,8\%$6,2 \%$, lebih rendah dari perkiraan sebelumnya 6,2\%-6,6\%. Konsumsi rumah tangga dan investasi diprakirakan juga sedikit tertahan sebagai dampak menurunnya daya beli akibat belum kuatnya permintaan ekspor dan pasca kenaikan harga BBM bersubsidi. Pertumbuhan ekonomi diprakirakan kembali meningkat pada triwulan IV-2013 dan berlanjut tahun 2014 yang diprakirakan pada kisaran 6,4\%-6,8\%. Nilai tukar rupiah pada triwulan II-2013 mengalami depresiasi sesuai dengan nilai fundamentalnya. Nilai tukar rupiah melemah sebesar 2,09\% (qtq) menjadi Rp9.925 per dolar AS, atau secara rata-rata melemah 1,03\% (qtq) menjadi Rp9.781 per dolar AS. Kondisi inflasi pada Juni 2013 meningkat cukup tinggi sebesar $1,03 \%(\mathrm{mtm})$ atau 5,90\% (yoy) disebabkan kenaikan harga bahan bakar bersubsidi dan bergerak lurus mendorong kenaikan harga barang.

Kondisi sistem keuangan tetap baik, meskipun pasar keuangan domestic sempat mendapat tekanan sebagai akibat sentimen global. Ini dapat ditunjukkan dengan rasio kecukupan modal (CAR/Capital Adequacy Ratio) yang masih tinggi sebesar $18,4 \%$ dan berada jauh di atas ketentuan minimum $8 \%$, serta rasio kredit bermasalah (NPL/Non Performing Loan) gross yang masih rendah sebesar 1,95\% pada bulan Mei 2013. Kredit modal kerja dan kredit investasi, meskipun juga berada dalam tren menurun, masih tumbuh cukup tinggi masing-masing sebesar $21,7 \%$ (yoy) dan 22,9\% (yoy), sedangkan pertumbuhan kredit konsumsi turun menjadi $18,4 \%$ (yoy). Bank Indonesia mencermati perkembangan KPR/KPA pada tipe-tipe 
tertentu tumbuh terlalu tinggi dan dikhawatirkan dapat mengganggu kinerja perbankan dan stabilitas sistem keuangan.

Pada triwulan III Bank Indonesia memutuskan untuk mempertahankan BI Rate pada level 7,25 \% dengan suku bunga Lending Facility dan suku bunga Deposit Facility tetap pada level 7.25\% dan 5.50.Perekonomian domestik diprakirakan tumbuh 5,6\% di Triwulan III-2013 dan untuk 2013 masih berada pada kisaran 5,5\%-5,9\%. Konsumsi rumah tangga dan investasi diprakirakan masih tertekan sebagai dampak dari menurunnya daya beli akibat tingginya tekanan harga pasca kenaikan harga BBM bersubsidi. Kinerja perekonomian nasional diprakirakan akan membaik pada tahun 2014, sejalan dengan perekonomian global dan harga komoditas yang diprakirakan membaik. Secara keseluruhan, perekonomian Indonesia diprakirakan tumbuh lebih tinggi mencapai 5,8\% - 6,2\%.

Nilai tukar rupiah pada triwulan ketiga 2013 mengalami depresiasi sejalan dengan nilai fundamentalnya. Secara rata-rata, rupiah melemah $8,18 \%$ (qtq) ke level Rp 10.652 per dolar AS atau terdepresiasi 14,29\% (qtq) ke level Rp 11.580 per dolar AS. Pada akhir triwulan ketiga 2013 tekanan rupiah berkurang sejalan dengan membaiknya kinerja inflasi dan neraca perdagangan serta sentimen positif penundaan tapering off oleh the Fed. Keyakinan pasar valas semakin pulih dengan permintaan dan penawaran yang semakin aktif dan berimbang dalam membentuk nilai tukar rupiah di pasar. Tekanan inflasi menurun dan mencatat deflasi sebesar 0,35\% (mtm) atau 8,40\% (yoy) pada September 2013. Lalu diikuti dengan penurunan harga sapi yang mengakibatkan turunnya harga kelompok volatile foods mencapai deflasi sebesar 3,38\% ( $\mathrm{mtm}$ ) atau inflasi 13,94\% (yoy).

Penurunan inflasi juga terjadi pada kelompok inti dan administered prices, masingmasing mencapai $0,57 \%(\mathrm{mtm})$ atau $4,72 \%$ (yoy) dan $0,34 \%(\mathrm{mtm})$ atau $15,47 \%$ (yoy). Dengan perkembangan tersebut, inflasi 2013 diprakirakan berada pada kisaran $9,0 \%-9,8 \%$, dan kemudian menurun pada kisaran sasaran $4,5 \pm 1 \%$ pada tahun 2014. Stabilitas sistem keuangan tetap terjaga dapat terlihat dengan rasio kecukupan modal CAR (CAR/Capital Adequacy Ratio) tetap tinggi mencapai $17,89 \%$, jauh di atas ketentuan minimum $8 \%$, sedangkan rasio kredit bermasalah (NPL/Non Performing Loan) tetap terjaga rendah sebesar 1,99\% pada bulan Agustus 2013. 
Berdasarkan penjelasan diatas bahwa penelitian ini dilakukan untuk menganalisis hubungan antara inflasi, jumlah uang beredar (M2), dan BI Rate yang dijadikan sebagai indikator pertumbuhan ekonomi di Indonesia. Tujuan dilakukan penelitian ini adalah untuk menganalisis seberapa besar korelasi antara inflasi, jumlah uang beredar (M2), dan BI Rate dalam mempengaruhi kebijakan pemerintah menjaga pertumbuhan ekonomi. Menganalisis implikasi ketiga variabel yaitu inflasi, jumlah uang beredar (M2), dan BI Rate terhadap perekonomian Negara. Menganalisis hubungan antara inflasi, BI Rate, dan jumlah uang beredar terhadap pertumbuhan ekonomi di Indonesia.

\section{METODE}

Penelitian ini menggunakan analisis korelasi pearson untuk mengetahui besaran hubungan antara BI Rate, Inflasi, dan jumlah uang beredar (M2) terhadap kebijakan pemerintah dalam mengendalikan ekonomi di tahun 2013. Data yang digunakan adalah data sekunder mulai dari Januari 2007 sampai dengan Desember 2013 dalam melihat pergerakan BI Rate, Inflasi, dan jumlah uang beredar (M2) sehingga dapat memberikan gambaran yang jelas mengenai hubungan korelasi antara ketiga variabel tersebut terhadap kebijakan pemerintah yang diambil dalam mengendalikan pertumbuhan ekonomi di tahun 2013.

Korelasi Pearson memiliki asumsi agar data harus berdistribusi normal dan data lebih dari 30 sampel. Data bersifat time series (waktu) sering tidak berdistribusi normal sehingga membutuhkan suatu metode untuk mengatasi asumsi tersebut. Penelitian ini menggunakan metode Transformasi Logaritma (Ln) untuk memenuhi asumsi bahwa data harus berdistribusi normal.

Uji korelasi bertujuan untuk menguji hubungan antara dua variabel yang tidak menunjukkan hubungan fungsional. Uji korelasi ini tidak membedakan jenis variabel (tidak ada variabel dependen maupun independen). Keeratan hubungan ini dinyatakan dalam bentuk koefisien korelasi. Uji korelasi terdiri dari Pearson, Spearman, dan Kendall.

Nilai koefisien korelasi merupakan nilai yang digunakan untuk mengukur kekuatan (keeratan) suatu hubungan antarvariabel. Korelasi Pearson dirumuskan bahwa koefisien korelasi memiliki nilai antara -1 hingga +1 . Sifat nilai koefisien korelasi adalah plus (+) atau minus (-). Hal ini menunjukkan arah korelasi. Makna sifat korelasi: 
1. Korelasi positif $(+)$ berarti jika variabel $X_{1}$ mengalami kenaikan maka variabel $X_{2}$ juga akan mengalami kenaikan maka atau jika variabel X2 mengalami kenaikan maka variabel X1 juga akan mengalami kenaikan.

2. Korelasi negatif (-) berarti jika variabel $X_{1}$ mengalami kenaikan maka variabel $X_{2}$ akan mengalami penurunan atau jika variabel $X_{2}$ mengalami kenaikan maka variabel $X_{1}$ akan mengalami penurunan.

Sifat korelasi akan menentukan arah dari korelasi. Keeratan korelasi dapat dikelompokkan sebagai berikut:

1. 0.00 sampai dengan 0.20 berarti korelasi memiliki keeratan sangat lemah.

2. 0.21 sampai dengan 0.40 berarti korelasi memiliki keeratan lemah.

3. 0.41 sampai dengan 0.70 berarti korelasi memiliki keeratan kuat.

4. 0.71 sampai dengan 0.90 berarti korelasi memiliki keeratan sangat kuat.

5. 0.91 sampai dengan 0.99 artinya korelasi memiliki keeratan sangat kuat sekali.

6. 1 berarti korelasi sempurna.

Tahapan pada penelitian ini adalah untuk memenuhi asumsi korelasi Pearson bahwa data harus berdistribusi normal. Uji yang digunakan adalah Jarque Bera dengan hipotesis sebagai berikut:

$\mathrm{Ho}=\mathrm{BI}$ Rate, Inflasi, dan jumlah uang beredar berdistribusi normal

$\mathrm{Ha}=\mathrm{BI}$ Rate, Inflasi, dan jumlah uang beredar (M2) tidak berdistribusi normal

Korelasi Pearson

Setelah asumsi untuk menganalisis korelasi Pearson bahwa data berdistribusi normal. Selanjutnya menganalisis ketiga hubungan variabel antara BI Rate, Inflasi, dan jumlah uang beredar (M2) dengan hipotesis sebagai berikut:

$\mathrm{Ho}_{1}=$ Jumlah uang beredar tidak berkorelasi dengan tingkat suku bunga (BI Rate)

$\mathrm{Ha}_{1}=$ Jumlah uang beredar (M2) berkorelasi dengan tingkat suku bunga (BI Rate).

$\mathrm{Ho}_{2}=$ Jumlah uang beredar tidak berkorelasi dengan inflasi.

$\mathrm{Ha}_{2}=$ Jumlah uang beredar (M2) berkorelasi dengan inflasi.

$\mathrm{Ho}_{3}=$ Tingkat suku bunga (BI Rate) tidak berkorelasi dengan inflasi.

$\mathrm{Ha}_{3}=$ Tingkat suku bunga (BI Rate) berkorelasi dengan inflasi. 


\section{HASIL DAN PEMBAHASAN}

Penelitian ini menganalisis pada dua tahapan yaitu uji normalitas dengan menggunakan uji Jarque Bera dan analisis korelasi antara BI Rate, Inflasi, dan jumlah uang beredar (M2) dengan menggunakan korelasi Pearson. Ketiga variabel yang dianalisis adalah BI Rate, Inflasi, dan jumlah uang beredar (M2). Dibawah ini hasil penelitian dan pembahasan sebagai berikut:

Proses analisis uji normalitas menggunakan uji Jarque-Bera dengan menggabungkan ketiga variabel yaitu inflasi, BI Rate, dan jumlah uang beredar (M2). Berdasarkan hasil diatas tahapan dalam menggunakan analisis korelasi pearson dara harus berdistribusi normal. Hasil menunjukkan bahwa dengan probability $0.856>0.05$ maka dapat disimpulkan Ho diterima dan Ha ditolak sehingga data ketiga variabel yaitu BI Rate, Inflasi, dan jumlah uang beredar (M2) berdistribusi normal. Jadi dalam proses analisis korelasi pearson asumsi data sudah terpenuhi. Data berdistribusi normal sangat penting dalam analisis korelasi untuk menjamin bahwa ketiga variabel layak digunakan sebagai penelitian dan memenuhi aspek ilmiah.

\section{Tabel 1. Uji Jarque Bera}

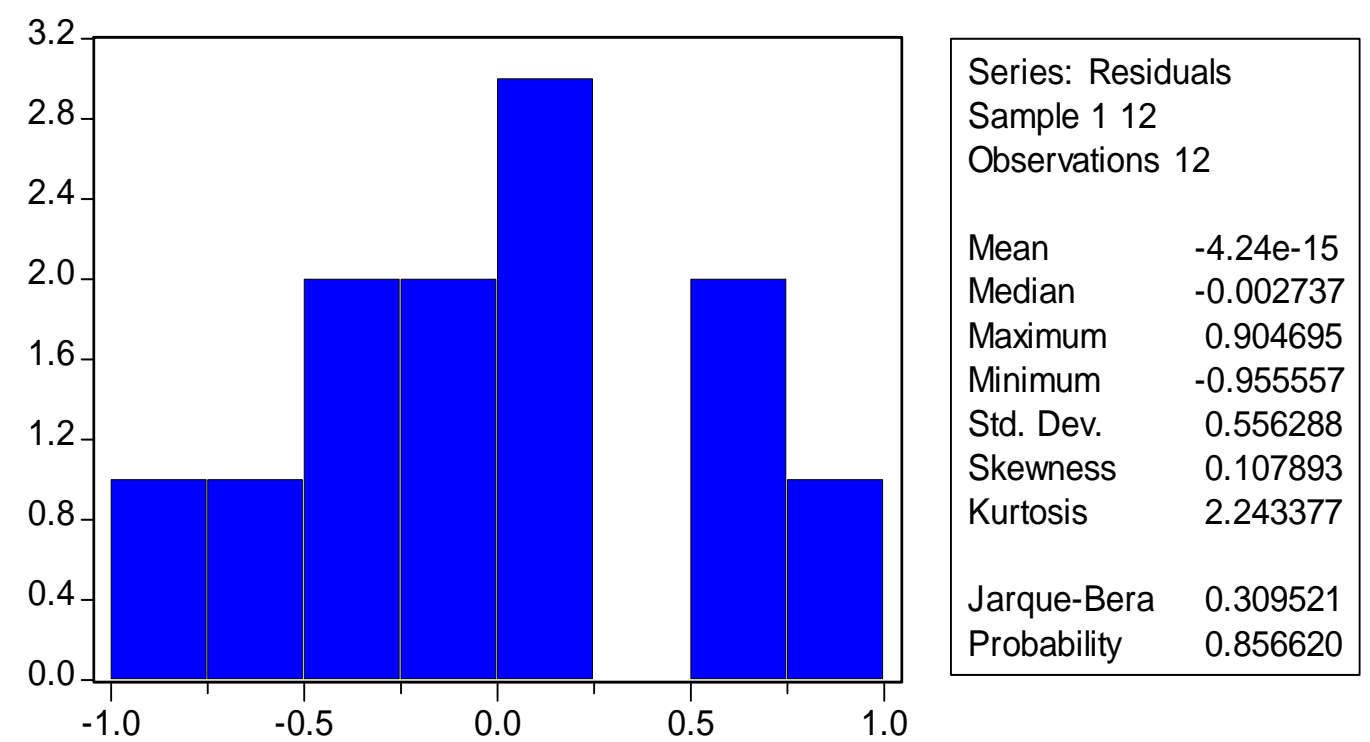

Tahapan selanjutnya adalah menganalisis hubungan antara BI Rate, Inflasi, dan jumlah uang beredar (M2) dengan menggunakan Korelasi Pearson. 
Tabel 2. Korelasi Pearson

\begin{tabular}{|c|c|c|c|c|}
\hline \multicolumn{5}{|c|}{ Correlations } \\
\hline & & BI RATE & INFLASI & M2 \\
\hline & Pearson Correlation & 1 & -.165 & .622 \\
\hline \multirow[t]{3}{*}{ BI RATE } & Sig. (2-tailed) & & .609 & .031 \\
\hline & $\mathrm{N}$ & 12 & 12 & 12 \\
\hline & Pearson Correlation & -.165 & 1 & .069 \\
\hline \multirow[t]{3}{*}{ INFLASI } & Sig. (2-tailed) & .609 & & .831 \\
\hline & $\mathrm{N}$ & 12 & 12 & 12 \\
\hline & Pearson Correlation & $.622^{*}$ & .069 & 1 \\
\hline \multirow[t]{2}{*}{ M2 } & Sig. (2-tailed) & .031 & .831 & \\
\hline & $\mathrm{N}$ & 12 & 12 & 12 \\
\hline
\end{tabular}

Pada Tabel 2 menunjukkan ada dua proses dalam melakukan analisis korelasi pearson yaitu nilai signifikansi dan nilai korelasi pearson. Nilai signifikansi menunjukkan bahwa ketiga variabel dapat mempengaruhi variabel lain. Nilai indikator untuk menyimpulkan bahwa setiap variabel memiliki hubungan dengan variabel lain jika nilai sig $<0.05$ maka dapat disimpulkan sebuah variabel memiliki hubungan dengan variabel lain. Nilai korelasi menunjukkan seberapa besar korelasi antara variabel apakah positif atau negatif dan bagaimana implikasinya terhadap variabel lain. Dibawah ini pembahasan untuk hasil penelitian sebagai berikut:

Nilai Signifikansi

Pada Tabel 2 menunjukkan bahwa dari ketiga ketiga variabel yaitu BI Rate, Inflasi, dan jumlah uang beredar (M2) tidak semua memiliki hubungan antara variabel. Hasil penelitian untuk nilai signifikansi sebagai berikut:

a) BI Rate dengan M2 memiliki hubungan korelasi yang dapat ditunjukkan bahwa nilai sig sebesar $0.031<0.05$ dimana Ho ditolak dan Ha diterima sehingga dapat disimpulkan bahwa BI Rate dengan jumlah uang beredar (M2) memiliki hubungan korelasi.

b) BI Rate dengan inflasi tidak memiliki hubungan korelasi yang dapat ditunjukkan bahwa nilai sig sebesar $0.609>0.05$ dimana Ho diterima dan Ha ditolak sehingga dapat disimpulkan bahwa $\mathrm{BI}$ Rate dengan inflasi tidak memiliki hubungan korelasi. 
c) Inflasi dengan M2 tidak memiliki hubungan korelasi yang dapat ditunjukkan bahwa nilai sig sebesar $0.831>0.05$ dimana Ho diterima dan Ha ditolak sehingga dapat disimpulkan bahwa Inflasi dengan jumlah uang beredar (M2) tidak memiliki hubungan korelasi.

Tahapan selanjutnya adalah menganalisis seberapa besar korelasi antara masingmasing variabel antara BI Rate, Inflasi, dan jumlah uang beredar (M2). Dibawah ini penjelasan mengenai analisis korelasi pearson untuk BI Rate, Inflasi, dan jumlah uang beredar (M2) sebagai berikut:

a) Korelasi BI Rate dengan Inflasi

Berdasarkan pada tabel 2 nilai korelasi BI Rate dengan inflasi sebesar -0.0165.Ini mengindikasikan bahwa korelasi antara BI Rate dengan Inflasi adalah korelasi sangat lemah. Korelasi yang terbentuk oleh BI Rate dengan inflasi dapat dianalisis bahwa setiap kenaikan atau penurunan tingkat BI Rate yang ditetapkan oleh Bank Indonesia belum tentu mempengaruhi kenaikan atau penurunan inflasi di Indonesia. Korelasi yang sangat lemah mengindikasikan bahwa kebijakan pemerintah dalam menaikkan BI Rate untuk mengendalikan inflasi belum tentu direspon dengan baik oleh pasar.

Melihat kondisi ekonomi Indonesia pada tahun 2013 dan kebijakan ekonomi yang diambil oleh Bank Indonesia dalam mengendalikan inflasi. Hasil penelitian ini terkait dengan kondisi ekonomi Indonesia tahun 2013. Pada Triwulan I, Bank Indonesia menetapkan BI Rate sebesar $5.75 \%$ dan sasaran tingkat inflasi $4.5 \%$.

Bank Indonesia memiliki target dengan menaikkan BI Rate mampu mengendalikan inflasi sehingga tingkat pertumbuhan ekonomi Indonesia dapat tercapai sesuai dengan target yang ditetapkan oleh pemerintah dan menjaga daya beli masyarakat. Akan tetapi, pada tingkat lapangan gejolak harga pangan mendorong inflasi sebesar $5.90 \%$. Ini diluar target pemerintah untuk menekan inflasi sampai dengan leve $4.5 \%$ demi menjaga tingkat pertumbuhan ekonomi Indonesia.

Pada Triwulan kedua Bank Indonesia menaikkan level BI Rate dari 5.75\% sampai $6.5 \%$ untuk mengendalikan inflasi yang sudah mencapai 5.90\%. Tingkat inflasi saat itu terjadi karena pemerintah menaikkan harga Bahan Bakar Bersubsidi (BBM) sehingga mengakibatkan kenaikan harga bahan pokok dan mengurangi daya beli masyarakat. Sampai pada akhir Triwulan kedua pemerintah tidak berhasil 
menurunkan tingkat inflasi dan kenaikan harga barang melonjak tajam sehingga mengakibatkan proses pertumbuhan ekonomi Indonesia menjadi lambat dan tidak sesuai dengan target pemerintah.

Pada Triwulan ketiga Bank Indonesia menaikkan level BI Rate dari 6.5\% sampai $7,25 \%$. Situasi inflasi pada saat itu mereda dan mencatat deflasi sebesar $0.35 \%$ pada September 2013. Akan tetapi, BI Rate belum mampu mengendalikan inflasi dan harus menunggu sampai tahun 2014 inflasi menurun sampai level $4.5 \%$.

Jadi dapat disimpulkan bahwa korelasi antara BI Rate dengan inflasi tidak berpengaruh signifikan dan memiliki korelasi negatif. Ini disebabkan setiap kebijakan Bank Indonesia dalam menaikkan BI Rate untuk mengendalikan inflasi selalu berbanding terbalik dengan situasi lapangan yang ada di masyarakat. BI Rate belum mampu mengendalikan inflasi sehingga membutuhkan waktu yang cukup lama dalam menurunkan inflasi sampai pada tingkat normal.

Korelasi BI Rate dengan Jumlah Uang Beredar (M2).

Berdasarkan hasil analisis data pada Tabel 2 menunjukkan adanya korelasi positif antara BI Rate dengan jumlah uang beredar (M2). Nilai korelasi antara BI Rate dengan jumlah uang beredar (M2) sebesar 0.622 yaitu korelasi kuat. Ini menunjukkan bahwa setiap kenaikan BI Rate mampu mengendalikan jumlah uang beredar. Ini sesuai dengan teori Dornbusch yang mengatakan bahwa setiap kenaikan suku Bunga berdampak positif pada pengendalian jumlah uang beredar. BI Rate merupakan alat yang digunakan oleh Bank Indonesia dalam mengendalikan pertumbuhan ekonomi di Indonesia.

Kebijakan pemerintah pada tahun 2013 dimulai pada triwulan pertama dengan mempertahankan level BI Rate sebesar $5.75 \%$ dengan tujuan mengendalikan tingkat inflasi dan pertumbuhan jumlah uang beredar. Sistem keuangan dan perbankan Indonesia memperlihatkan kondisi yang positif. Pertumbuhan ekonomo global yang mengalami penurunan dan belum ada kepastian membaik tidak berpengaruh pada kondisi ekonomi di Indonesia. Jumlah uang beredar (M2) di Indonesia memperlihatkan kondisi yang positif sehingga setiap kenaikan BI Rate direspon positif oleh sektor keuangan dan perbankan. 
Setiap level kenaikan BI Rate dimulai pada bulan Januari 2013 sampai dengan Desember 2013 menunjukkan bahwa terdapat korelasi yang kuat untuk mengendalikan jumlah uang beredar (M2). Sektor perbankan dan keuangan mampu mengatasi kenaikan BI Rate dengan positif sehingga jumlah uang beredar (M2) yang ada di tangan masyarakat dapat diserap dengan baik. Ini sesuai dengan nilai signifikansi antara BI Rate dengan jumlah uang beredar (M2) yaitu memiliki pengaruh dan korelasi yang kuat sehingga dapat disimpulkan bahwa kebijakan pemerintah dalam menaikkan BI Rate untuk mengendalikan jumlah uang beredar (M2) sudah tepat dan mampu mempertahankankan tingkat pertumbuhan ekonomi di Indonesia.

b) Korelasi Inflasi dengan Jumlah Uang Beredar (M2)

Berdasarkan hasil analisis pada tabel 2 menunjukkan bahwa korelasi antara Inflasi dengan jumlah uang beredar (M2) terdapat korelasi yang lemah. Nilai korelasi antara inflasi dengan jumlah uang beredar sebesar 0.069. Ini menunjukkan bahwa setiap kenaikan inflasi tidak secara langsung dapat mempengaruhi jumlah uang beredar di Indonesia (M2).

Berdasarkan penelitian yang dilakukan oleh Putu Motavia menjelaskan bahwa jumlah uang beredar memiliki korelasi positif dengan inflasi. Penelitian ini menganalisis bahwa terdapat hubungan positif antara BI Rate dengan inflasi dimana setiap inflasi terjadi memiliki dampak langsung kepada kenaikan harga barang sehingga mampu mempengaruhi daya beli masyarakat. Jumlah uang beredar (M2) yang ada di masyarakat tetap terserap baik oleh sektor perbankan.

Perbedaan pada penelitian ini adalah bahwa hasil penelitian menunjukkan bahwa inflasi dengan jumlah uang beredar (M2) memiliki pengaruh dengan tingkat korelasi yang lemah sehingga masalah inflasi di Indonesia bisa berefek negatif pada jumlah uang beredar (M2), tetapi kondisi tersebut tidak mengakibatkan penurunan yang signifikan terhadap daya beli masyarakat di pasar.

Pada tahun 2013 kondisi perekonomian Indonesia secara relatif stabil. Situasi perekonomian Indonesia tumbuh dan kondisi keuangan Indonesia stabil. Target pemerintah untuk menekan inflasi sampai $4.5 \%$ memilik efek langsung pada kenaikan BI Rate. Pemerintah menaikkan harga Bahan Bakar Bersubsidi (BBM) yang mengakibatkan inflasi naik sehingga ditakutkan mempengaruhi penurunan 
daya beli masyarakat. Melihat situasi ini bahwa korelasi inflasi dengan jumlah uang beredar pada tahun 2013 memiliki korelasi positif dan lemah disebabkan kondisi ekonomi Indonesia stabil dan positif. Berdasarkan hasil penelitian bahwa tingkat korelasi antara BI Rate dengan uang beredar (M2) memiliki hubungan negatif. Ini menunjukkan bahwa setiap kenaikan BI Rate dapat menurunkan jumlah uang beredar (M2).

\section{SIMPULAN}

Penelitian ini dilakukan untuk melihat hubungan korelasi antara BI Rate, Inflasi, dan jumlah uang beredar (M2) dengan melihat kondisi faktual mengenai kebijakan pemerintah untuk mempertahankan dan mengendalikan pertumbuhan ekonomi di Indonesia. Penelitian ini menyimpulkan bahwa penyebab korelasi negatif antara $\mathrm{BI}$ Rate dengan inflasi karena setiap kenaikan BI Rate tidak memiliki dampak langsung dengan inflasi. BI Rate memerlukan waktu yang lama untuk menekan inflasi sampai pada tingkat normal yaitu $4.5 \%$.

Kemudian korelasi BI Rate dengan jumlah uang beredar (M2) memiliki korelasi yang kuat ini disebabkan bahwa setiap kenaikan BI Rate yang dilakukan oleh Bank Indonesia bisa berdampak langsung pada jumlah uang beredar (M2) yang ada pada masyarakat. Kondisi riil yang ada bahwa sektor perbankan dan keuangan Indonesia mampu merespon positif dengan keputusan Bank Indonesia dalam menaikkan BI Rate untuk mengendalikan inflasi dan jumlah uang beredar (M2). Korelasi inflasi dengan jumlah uang beredar (M2) cenderung lemah dan positif ini dapat disimpulkan bahwa setiap kenaikan inflasi belum tentu direspon baik oleh pasar sehingga jumlah uang beredar (M2) pada tahun 2013 cenderung stabil dan positif.

\section{PUSTAKA ACUAN}

Bank Indonesia. Statistik Ekonomi dan Keuangan Indonesia (beberapa edisi).

Bank Indonesia, Laporan Tinjauan Kebijakan Moneter Triwulan I - III Tahun 2013.

Baasir, F. 2003. Pembangunan dan Krisis. Jakarta:Pustaka Harapan

Boediono. 1992. Ekonomi Moneter. Edisi ketiga. BPFE. Yogyakarta.

Biro Pusat Statistik. Laporan Data Inflasi 2001-2010 (beberapa edisi).

Frederic S. Miskhin. 2001. The Economics of Money Banking, and Financial Markets. USA : Pearson Education International. USA or Canada, Edisi 6. 
Dornbusch, Rudiger Julius and Stanley Fisher. 2008. Macroeconomics Fourth Edition. Singapura: McGraw-Hill.

Mankiw, N. Gregory. 2002. Principle of Economics Third Edition. Thomson. Edisi Indonesia. Jakarta : Erlangga.

Michael. 2012. Fisher Effect Hubungan Antara Tingkat Bunga Dan Jumlah Uang Beredar Di Indonesia (Pendekatan Autoregressive Model "Distributed"Lag). Forum Ekonomi Vol. XV No. 2 Juli 2012, Mulawarman University.

Nopirin. 2000. Ekonomi Moneter. Buku II, Edisi I, Cetakan X. Yogyakarta : BPFE.

Nugroho. Maruto. 2012. Analisis Faktor Yang Mempengaruhi Inflasi di Indonesia periode 2000.1 - 2011.4. Jurnal Ekonomi. Universitas Diponegoro. Vol 1, No 1.

Susanti, Hera, Moh. Ikhsan, dan Widyanti. 2000. Indikator-Indikator Makroekonomi ed. 2. Jakarta: Lembaga Penerbit FEUI.

Winarno, Wing Wahyu. 2002. Analisis Ekonometrika dan Statistika Dengan Eviews. Yogyakarta : UPP STIM YKPN.

Hamzah, Muhammad Zilal 2006. Pengaruh Uang Beredar, Pengeluaran Pemerintah, Dan Nilai Tukar Terhadap Inflasi di Indonesia: Pendekatan Error Correction Model (ECM). Jurnal Kebijakan Ekonomi, Vol. 2, No. 1 Agustus. 